\title{
PENGARUH LAYANAN INFORMASI MENGGUNAKAN PAPAN BIMBINGAN TERHADAP PEMAHAMAN KARIR SISWA SEKOLAH DASAR
}

\author{
Miranti Widi Andriani \\ STKIP PGRI Bangkalan \\ $\underline{\text { mirantiwidi@stkippgri-bkl.ac.id }}$
}

\begin{abstract}
Career understanding is interpreted as an individual effort to understand themselves both attitudes, abilities, and interests. The importance of understanding career and workplace information is a separate task for individuals. In elementary schools (ES), career understanding is a problem that is often experienced by students. This occurs when students feel unsure about what career path to choose in the future and how to formulate strategies so that their abilities and goals can be realized. Students also have not been able to determine the abilities, talents and interests that have caused confusion and certainly need guidance. The researcher considers it is necessary to implement information services using guidance boards as an effort to help students improve their career understanding. This research's method of research is Quasi-Experimental Design which uses the equivalent time-series design. On the basis of the results of the study, it can be concluded that information services using a guidance board can affect the career understanding of elementary school students. Group analysis is done by tabulating and illustrating the pretest and posttest score charts. Visually, the results of the study indicate there is an increase in career understanding which includes self-understanding and knowledge of the workforce. Implications for further research that can be obtained is the theoretical findings in this study can be used as information in the field of guidance regarding career understanding in elementary school students, this is seen from the increasing test results.
\end{abstract}

Keywords:

guidance board, career understanding, elementary school

\begin{abstract}
ABSTRAK
Pemahaman karir dimaknai sebagai usaha individu untuk memahami diri baik sikap, kemampuan, dan minatnya. Pentingnya pemahaman terhadap informasi karir dan dunia kerja menjadi tugas tersendiri bagi individu. Di Sekolah Dasar (SD) pemahaman karir merupakan permasalahan yang sering dialami siswa. Hal ini muncul saat siswa merasa tidak yakin akan memilih jenjang karir apa di masa depan dan bagaimana menyusun strategi agar kemampuan dan cita-citanya dapat terwujud. Siswa juga belum dapat menentukan kemampuan, bakat dan minat yang dimilikinya sehingga menyebabkan kebingungan dan tentu membutuhkan bimbingan. peneliti memandang perlu untuk menerapkan layanan informasi menggunakan papan bimbingan sebagai upaya membantu siswa meningkatkan pemahaman karirnya. Jenis penelitian ini adalah Quasi Experimental Design yang menggunakan desain penelitian equivalent time series design. Atas dasar hasil penelitian dapat diperoleh kesimpulan layanan informasi menggunakan papan bimbingan dapat mempengaruhi pemahaman karir siswa sekolah dasar. Analisis kelompok dilakukan dengan cara mentabulasi dan menggambarkan grafik skor pretest dan postest. Secara visual, hasil penelitian menunjukkan ada peningkatan pemahaman karir yang meliputi pemahaman diri dan pemahaman dunia kerja. Kesimpulan yang dapat diperoleh adalah temuan teoritis dalam penelitian ini dapat dijadikan sebagai informasi dalam bidang bimbingan mengenai pemahaman karir pada siswa sekolah dasar, hal ini dilihat dari meningkatnya hasil test.
\end{abstract}

\section{KataKunci}

papan

bimbingan,

pemahaman

karir, sekolah

dasar 


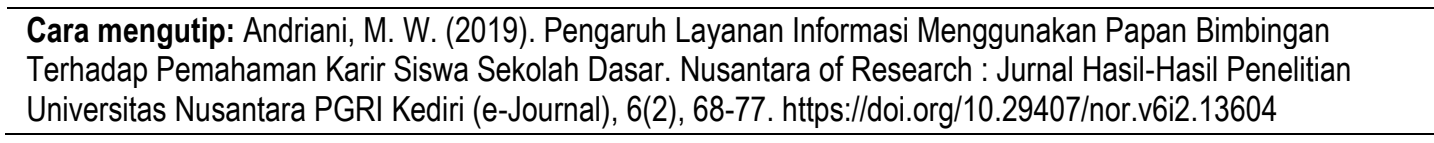

\section{PENDAHULUAN}

Bidang bimbingan karir dalam tugas perkembangan individu adalah hal yang penting. Gibson dan Mitchell (2011) menjelaskan karir selalu berhubungan dengan pola perilaku dan pola tindak individu yang terangkai dalam pengalaman diri berkaitan aktivitas kerja baik yang sedang dilakukan maupun yang akan mendatang sebagai sebuah proses yang berkelanjutan. Karir dapat diperkenalkan sejak dini demi mempersiapkan diri dalam pemilihan karir yang akan dilalui siswa. Buku panduan khusus bimbingan dan konseling yang mengkhususkan arah peminatan, dijelaskan bahwa pada jenjang SD, tugas sekolah adalah mengarahkan siswa mempersiapkan diri pada jenjang yang lebih tinggi dan memberikan pengertian awal tentang bekerja dan pekerjaan. Dapat dimaknai bahwa pemahaman karir merupakan bagian penting yang harus dimiliki siswa.

Pemahaman karir dapat dimaknai sebagai usaha individu untuk memahami diri baik sikap, kemampuan, dan minatnya. Individu kemudian menata diri untuk menguasai tentang dunia karir dan informasi karir. Di Sekolah Dasar (SD) pemahaman karir merupakan permasalahan yang sering dialami siswa. Hal ini muncul saat siswa merasa tidak yakin akan memilih jenjang karir apa di masa depan dan bagaimana menyusun strategi agar kemampuan dan cita-citanya dapat terwujud. Siswa juga belum dapat menentukan kemampuan, bakat dan minat yang dimilikinya sehingga menyebabkan kebingungan dan tentu membutuhkan bimbingan.

Pertimbangan pemahaman karir diprioritaskan untuk bekal siswa. Bekal tersebut dimaksudkan agar siswa mampu mengetahui tentang karir pilihan yang sesuai dengan tipe kepribadiannya. Siswa juga diharapkan mampu memilih lingkungan pekerjaannya yang diminatinya. Kesesuaian antara pilihan karir dengan pemahaman diri seperti bakat dan minat akan menentukan kepuasan yang akan diperoleh. Holland (dalam Glading, 2012) mengatakan sangat penting bagi individu untuk memiliki pemahaman yang cukup mengenai diri dan lingkungan pekerjaan sebagai kajian untuk bisa memilih karir.

Di SD dengan belum adanya posisi struktural konselor berimbas pada kurangnya fasilitas untuk membantu meningkatkan pemahaman karir siswa. Sejauh ini yang langkah yang telah dilakukan guru masih berfokus pada pemberian layanan informasi, mengenai studi lanjut apa saja yang dapat diambil dengan berdasarkan nilai matapelajaran para siswa. Namun langkah tersebut dirasa masih kurang efektif dalam memberikan pemahaman karir siswa. Kemasan layanan informasi yang menarik dapat meningkatkan animo siswa untuk memahami dengan baik, begitu pula pemahaman terhadap karir. Layanan informasi yang menarik yang dimaksud adalah papan bimbingan sebagai media bimbingan dan konseling untuk membantu pemahaman karir siswa SD.

Fenomena yang mendasari penelitian ini adalah, di masyarakat saat ini, khususnya siswa SD, siswa masih belum memahami baik diri dan lingkungan pekerjaan yang sangat dibutuhkan untuk jenjang karir. Pemahaman karir salah satunya dapat dilihat dari cara siswa 
memahami jenis-jenis pekerjaan dan syarat yang sesuai dan dibutuhkan. Siswa belum dapat mamahami hubungan antara pekerjaan sesuai dengan tipe kepribadian, dan bagaimana analisis kekuatan dan kelemahan pribadi. Kebanyakan siswa menjawab akan mengikuti arahan orang tua dalam memilih sekolah lanjutan dan jenjang karir yang diinginkan orang tua. Hal ini sangat mengkhawatirkan dimana karir akan dipatokkan pada strandar tingginya pendapatan yang akan diperoleh daripada pengoptimalan kemampuan diri dalam memilih karir.

Fenomena tersebut bedasarkan pada kondisi riil menganai tingkat pemahaman karir siswa SD, merujuk pada penelitian survey Wijaya (2017) kepada 257 mengenai tingkat pemahaman karir siswa SD, ditemukan persentase sebesar 35,02\% tingkat pemahaman karier siswa SD kelas rendah. Temuan kedua sebesar $36,58 \%$ diketahui pada indikator menerjemahkan pemahaman karir tergolong pada pada kategori tinggi. Temuan ketiga ditemukan pada indikator menafsirkan pemahaman karir berada pada kategori sedang dengan persentase 40,86\%. Sedangkan pada indikator pemahaman mengekstrapolasi pemahaman karir ditemukan persentase $44,75 \%$ yang tergolong pada kategori sedang.

Kondisi riil tersebut jika dihubungkan dengan tugas perkembangan siswa SD mengenai karir maka akan ditemukan kesenjangan. Hal ini dapat dilihat dalam panduan Depdiknas (2007) yang mencatumkan SKKPD (Standar Kompetensi Kemandirian Peserta Didik) aspek perkembangan wawasan dan kesiapan karir di sekolah dasar antara lain: a) Pengenalan: siswa SD diharapkan mengenal ragam/macam pekerjaan dan mengenal aktivitas individu dalam kehidupan, b) Akomodasi: siswa SD diharapkan dapat menghargai ragam/macam pekerjaan dan memahami aktivitas individu sebagai hal saling terkait, c) tindakan: siswa SD diharapkan mengekspresikan ragam/macam pekerjaan dan pola-pola kegiatan serta aktivitas individu di lingkungan kehidupannya. Oleh karena itu perlu adanya perhatian khusus terhadap tugas perkembangan karir siswa di SD.

Menelisik lebih jauh mengenai kesenjangan yang ada antara tugas perkembangan karir siswa SD dengan kondisi riil di lapangan, tentu ini menjadi perhatian khusus mengingat harus terbentuknya pondasi yang baik dalam pemahaman karir. Kurangnya pemahaman karir berakibat kurang mampunya siswa dalam mengenali macam-macam karir yang berkembang saat ini berserta syarat memasukinya, dimana hal tersebut dapat berimbas pada ketidakmampuan siswa dalam mengambil keputusan karir yang akan dipilihnya. Minimnya pemahaman karir yang dimiliki siswa menjadikan siswa sering kali melakukan kesalahan dalam mengambil keputusan karir yang akan ditekuninya.

Solusi yang ingin dibuktikan kefektifannya adalah dengan menggunakan papan bimbingan sebagai media untuk meningkatkan pemahaman karir siswa SD. Penelitian terdahulu mengenai penggunaan layanan bimbingan diantaranya Fitrianti dkk (2017) menunjukkan adanya peningkatan perilaku menjaga kebersihan kelas setelah mengikuti layanan informasi kebersihan kelas disertai papan bimbingan. Senada dengan hal tersebut berdasarkan hasil analisis data ditemukan pengaruh layanan informasi dengan media papan bimbingan terhadap sikap kemandirian siswa (Frandikga dan Hartini, 2018). Berdasarkan beberapa temuan diatas tampaknya papan bimbingan akan menjadi media yang tepat untuk meningkatkan pemahaman karir siswa SD. 
Pemilihan solusi di atas jika dosoroti dari teori Holland (1985) dengan jelas telah dipaparkan bahwa dalam memilih pekerjaan individu menggabungkan semua aspek dalam kehidupannya baik dari lingkungan, keluarga, teman, sekolah dan budayanya. Pemikiran Holland yang dapat menjadi dasar untuk menanamkan pondasi yang baik dalam pemahaman karir siswa SD adalah mengenai inventori kepribadian yang disusun atas dasar minat. Minat atau bisa disebut kesenangan pribadi merupakan modal utama yang didapat dari lingkungan keluarga/keturunan. Individu memilih sebuah karier akan merujuk pada tujuan memenuhi kepuasan melalui kesenangan/minatnya. Individu dapat belajar mengembangkan minat sehingga pengambilan keputusan karir akan mengerucut pada pemenuhan kesenangan sehingga terbuka kemungkinan baginya mendapatkan kepuasan dalam lingkungan pekerjaan yang sesuai.

Berdasarkan uraian diatas, secara teoritis dapat disimpulkan bahwa layanan informasi menggunakan media papan bimbingan dapat mempengaruhi tingkat pemahaman karir siswa SD. Oleh karena itu, peneliti memandang perlu untuk menerapkan layanan informasi menggunakan papan bimbingan sebagai upaya membantu siswa meningkatkan pemahaman karirnya.

\section{METODE}

Penelitian ini merupakan penelitian kuantitatif dengan rancangan Quasi Experimental Design. Pemilihan desain eksperimen ini berdasarkan kriteria-kriteria antara lain: 1) merupakan desain yang tepat untuk menguji hipotesis penelitian, 2) sesuai untuk dilakukan dalam bidang ilmu sosial, 3) rancangan ini menguji secara langsung efektivitas suatu variabel terhadap variabel lain, 4) rancangan ini hanya menggunakan kelompok eksperimen. Pelaksanaan penelitian diawali pengukuran sebelum treatment yang dilanjutkan dengan memberikan treatment. Setelah proses treatment dilakukan pengukuran hasil pengaruh yang diakibatkan perlakuan atau treatment.

Equivalent time series design dipilih sebagai desain penelitian (Creswell, 2012: 315). Dasar pertimbangan penggunaan desain ini adalah: 1) Hanya menggunakan satu kelompok saja yakni kelompok eksperimen (tanpa kelompok kontrol), 2) penempatan kelompok eksperimen menggunakan kelompok intact (kelompok yang sudah ada), dengan penentuan sampel tidak dilakukan secara random, 3) desain ini mengukur skor post-test setelah diberikan intervensi / treatment.

Penelitian yang dilakukan dengan subjek siswa kelas V, di SDN Pejagan 6 Bangkalan ini menggunakan instrumen penelitian pemilihan karir (alat ukur yang disusun dan dikembangkan dalam penelitian ini adalah instrumen pemahaman karir menurut teori Holland), pedoman wawancara, dan angket. Analisis data dimaksudkan untuk memberikan makna terhadap data yang dikumpulkan dari subjek penelitian. Analisis data yang digunakan dalam penelitian ini adalah analisis data visual. Analisis data visual ini merupakan penginterpretasian data yang tergambar dalam grafik. Untuk pemeriksaan visual penyajian data grafik, diperhatikan level, central trendecy, dan trend (Alberto \& Troutmant, 1991). 


\section{HASIL}

\section{Skor Pretes dan Postest}

Skor pretes dan postes dimaksudkan untuk mengetahui skor yang diperoleh oleh siswa. Peningkatan skor yang diperoleh sebelum dan sesudah pemberian treatment akan dapat menunjukkan hasil belajar atau pemahaman siswa terhadap materi yang disampaikan pada sesi treatment.Tabulasi skor pretest pemahaman karir siswa dapat dilihat pada tabel 1.

Tabel 1. Perbandingan Skor Angket Pemahaman Karir Sebelum dan Sesudah Mendapatkan Intervensi.

\begin{tabular}{|c|c|c|c|c|c|}
\hline No & Subjek & $\begin{array}{l}\text { Jumlah Skor } \\
\text { Pemahaman } \\
\text { Karir (Pretest) }\end{array}$ & $\begin{array}{c}\text { Jumlah Skor } \\
\text { Pemahaman } \\
\text { Karir (Postest 1) }\end{array}$ & $\begin{array}{c}\text { Jumlah Skor } \\
\text { Pemahaman } \\
\text { Karir (Postest 2) }\end{array}$ & $\begin{array}{c}\text { Jumlah Skor } \\
\text { Pemahaman } \\
\text { Karir (Postest 3) }\end{array}$ \\
\hline 1 & A & 19 & 25 & 29 & 32 \\
\hline 2 & $B$ & 22 & 27 & 32 & 34 \\
\hline 3 & $\mathrm{C}$ & 24 & 29 & 32 & 35 \\
\hline 4 & D & 19 & 26 & 30 & 34 \\
\hline 5 & $E$ & 20 & 26 & 29 & 35 \\
\hline 6 & $\mathrm{~F}$ & 21 & 27 & 32 & 36 \\
\hline 7 & G & 21 & 25 & 29 & 33 \\
\hline 8 & $\mathrm{H}$ & 22 & 29 & 32 & 36 \\
\hline 9 & I & 18 & 25 & 30 & 34 \\
\hline 10 & $\mathrm{~J}$ & 18 & 24 & 26 & 31 \\
\hline 11 & $\mathrm{~K}$ & 18 & 26 & 30 & 36 \\
\hline 12 & L & 20 & 27 & 32 & 37 \\
\hline 13 & $M$ & 20 & 26 & 32 & 37 \\
\hline 14 & $\mathrm{~N}$ & 22 & 27 & 34 & 37 \\
\hline 15 & 0 & 23 & 28 & 36 & 36 \\
\hline 16 & $\mathrm{P}$ & 23 & 27 & 35 & 37 \\
\hline 17 & $Q$ & 22 & 29 & 35 & 37 \\
\hline 18 & $\mathrm{R}$ & 20 & 27 & 35 & 37 \\
\hline 19 & $S$ & 20 & 25 & 32 & 35 \\
\hline \multirow[t]{3}{*}{20} & $\mathrm{~T}$ & 18 & 26 & 33 & 36 \\
\hline & Total & 410 & 531 & 635 & 705 \\
\hline & Mean & 20,5 & 26,55 & 31,75 & 35,25 \\
\hline
\end{tabular}

Perbandingan perolehan bila digambarkan dengan diagram dapat dilihat dalam gambar 1.

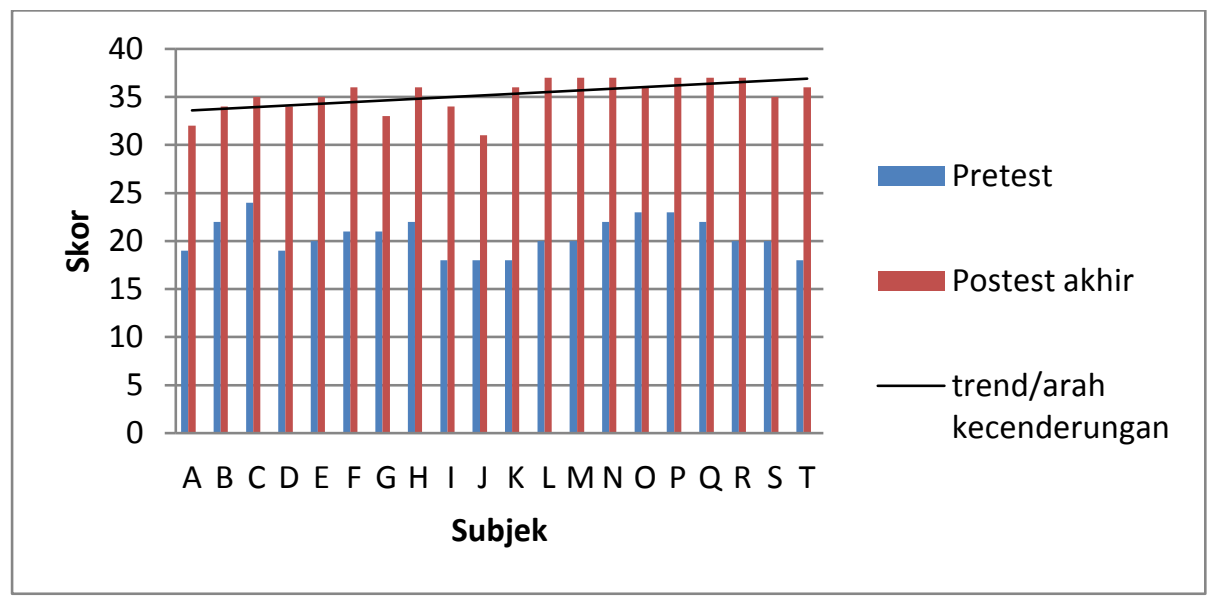

Gambar 1. Perbedaan Skor Pretest dan Postest Angket Pemahaman Karir Siswa SD 
Dari gambar ini dapat dilihat bahwa hasil pretes dan postest masing-masing siswa mengalami kenaikan. Tentu hal ini terjadi setelah dilakukan sesi treatment. Maka diperoleh pula trend/arah kecenderungan berbanding lurus mengalami kenaikan dengan hasil postes.

\section{Analisis Data Kelompok}

Analisis kelompok dilakukan dengan cara mentabulasi dan menggambarkan grafik skor pretest, postest treatment 1, postest treatment 2, dan postest treatment 3 secara kelompok berdasarkan skor individu untuk masing-masing indikator capaian pemahaman karir. Adapun hasil analisis kelompok akan dijabarkan sebagai berkut:

\section{Pemahaman Diri}

Tabel 2. Pengukuran Secara Kelompok Untuk Indikator Pemahaman Diri

\begin{tabular}{|c|c|c|c|}
\hline No & Subjek & $\begin{array}{c}\text { Skor Pretest } \\
\text { Pemahaman Diri }\end{array}$ & $\begin{array}{c}\text { Skor Postest Pemahaman } \\
\text { Diri setelah treatment } 3\end{array}$ \\
\hline 1 & $\mathrm{~A}$ & 10 & 16 \\
\hline 2 & $\mathrm{~B}$ & 10 & 16 \\
\hline 3 & $\mathrm{C}$ & 12 & 17 \\
\hline 4 & $\mathrm{D}$ & 9 & 16 \\
\hline 5 & $E$ & 9 & 17 \\
\hline 6 & $\mathrm{~F}$ & 11 & 17 \\
\hline 7 & $\mathrm{G}$ & 12 & 17 \\
\hline 8 & $\mathrm{H}$ & 9 & 15 \\
\hline 9 & 1 & 9 & 14 \\
\hline 10 & $\mathrm{~J}$ & 10 & 16 \\
\hline 11 & $\mathrm{~K}$ & 8 & 16 \\
\hline 12 & $\mathrm{~L}$ & 8 & 16 \\
\hline 13 & $\mathrm{M}$ & 9 & 16 \\
\hline 14 & $\mathrm{~N}$ & 12 & 18 \\
\hline 15 & 0 & 11 & 18 \\
\hline 16 & $\mathrm{P}$ & 9 & 16 \\
\hline 17 & $Q$ & 10 & 19 \\
\hline 18 & $\mathrm{R}$ & 10 & 20 \\
\hline 19 & $S$ & 9 & 15 \\
\hline \multirow[t]{3}{*}{20} & $\mathrm{~T}$ & 8 & 17 \\
\hline & Total & 195 & 332 \\
\hline & Mean & 9,75 & 16,6 \\
\hline
\end{tabular}

Berdasarkan pada tabel 2 maka apabila divisualisaikan dalam bentuk grafik dapat dilihat pada gambar 2. Pada gambar ini dapat dilihat pula pemahaman diri siswa mengalami kenaikan setelah dilakukan sesi treatment. Beberapa subjek mengalami kenaikan skor hingga dua kali lipat seperti subjek $R$ yang mengalami kenaikan dari skor 10 poin menjadi 20 poin. 
Andriani

Pengaruh Layanan Informasi Menggunakan Papan Bimbingan Terhadap Pemahaman Karir Siswa...

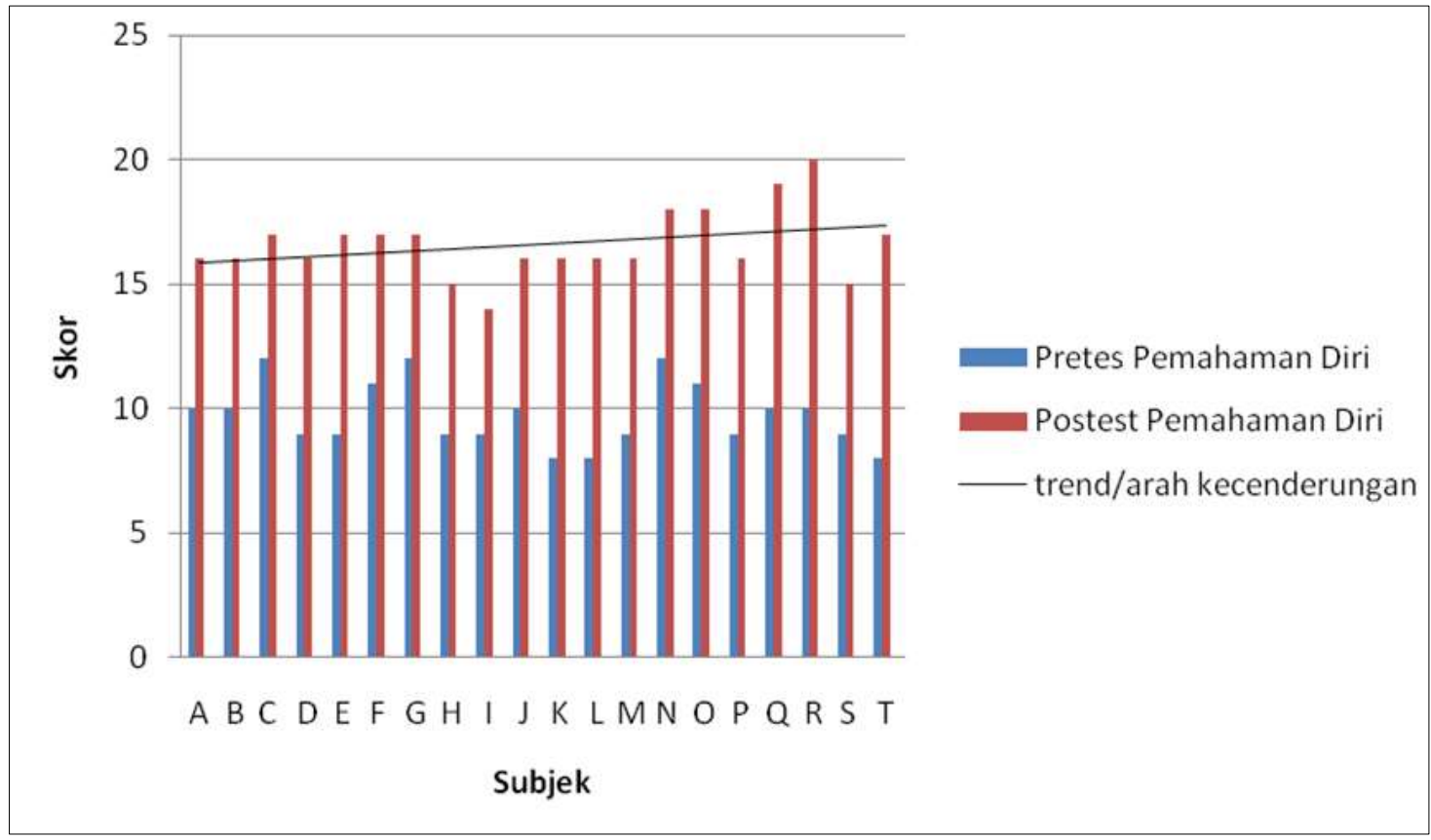

Gambar 2. Grafik Pemahaman Diri Sebelum dan Sesudah Intervensi

\section{Pemahaman Dunia Kerja}

Tabel 3. Pengukuran Secara Kelompok Untuk Indikator Pemahaman Dunia Kerja

\begin{tabular}{|c|c|c|c|}
\hline No & Subjek & $\begin{array}{c}\text { Skor Pretest Pemahaman } \\
\text { Dunia Kerja }\end{array}$ & $\begin{array}{c}\text { Skor Postest Pemahaman Dunia Kerja } \\
\text { setelah treatment } 3\end{array}$ \\
\hline 1 & A & 9 & 16 \\
\hline 2 & $\mathrm{~B}$ & 12 & 18 \\
\hline 3 & C & 12 & 18 \\
\hline 4 & $\mathrm{D}$ & 10 & 18 \\
\hline 5 & $E$ & 11 & 18 \\
\hline 6 & $\mathrm{~F}$ & 10 & 19 \\
\hline 7 & G & 9 & 16 \\
\hline 8 & $\mathrm{H}$ & 13 & 21 \\
\hline 9 & I & 9 & 20 \\
\hline 10 & $\mathrm{~J}$ & 9 & 16 \\
\hline 11 & K & 10 & 20 \\
\hline 12 & $\mathrm{~L}$ & 12 & 21 \\
\hline 13 & $M$ & 11 & 21 \\
\hline 14 & $\mathrm{~N}$ & 10 & 19 \\
\hline 15 & 0 & 12 & 18 \\
\hline 16 & $P$ & 14 & 21 \\
\hline 17 & $Q$ & 12 & 18 \\
\hline 18 & $\mathrm{R}$ & 10 & 17 \\
\hline 19 & $S$ & 11 & 20 \\
\hline \multirow[t]{3}{*}{20} & $\mathrm{~T}$ & 10 & 19 \\
\hline & Total & 216 & 374 \\
\hline & Mean & 10,8 & 18,7 \\
\hline
\end{tabular}


Apabila divisualisaikan dalam bentuk grafik dapat dilihat pada gambar 3

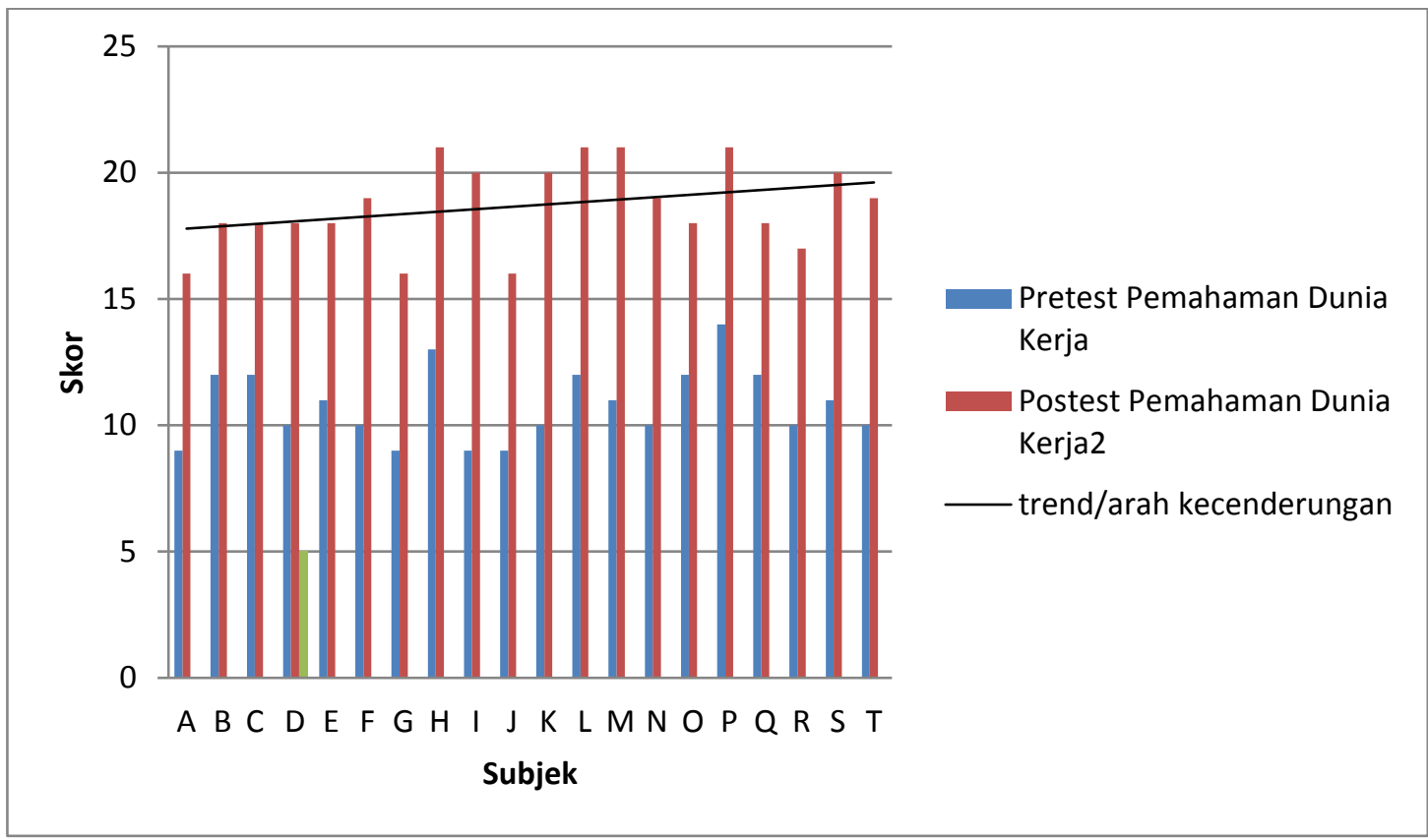

Gambar 3 Grafik Pemahaman Dunia Kerja Sebelum dan Sesudah

Senada dengan hadil kenaikan skor di aspek pemahaman diri, aspek pemahaman dunia kerja juga mengalami kenaikan. Trend/arah kecenderungan menunjukkan seluruh subjek mengalami kenaikan dalam aspek memahami dunia kerja lebih baik dari sebelum mendapat traetment.

\section{PEMBAHASAN}

Berdasarkan hasil penelitian dapat disimpulkan pemahaman diri siswa mengalami kenaikan setelah dilakukan sesi treatment. Pemahaman diri siswa mencakup: kemampuan/kecakapan yang dimiliki, minat, cita-cita, ciri spesifik, kondisi fisik dan kesehatan. Memahami minat menjadi salah satu bagian yang dapat digunakan dalam proses pengambilan keputusan individu dalam menentukan karir. Melibatkan minat dalam menekuni pekerjaan akan menambah ketenangan dan kenyamanan seseorang. Sesuai dengan pemikiran Holland bahwa tingkat pemahaman karir yang baik menunjukkan tingkat keakuratan individu dalam memilih alternatif pilihan. Jika semua alternatif yang muncul dalam pilihan karir tersebut dikaitkan dengan tipe kepribadian seseorang, maka tingginya tingkat kecocokan antara pekerjaan/ minat karir akan berbanding lurus dengan meningkatknya kepuasan seseorang dengan pekerjaannya.

Pemahaman diri tentu harus mendapat dukungan dari lingkungan terdekat, baik orang tua maupun sekolah. Holland (dalam Gladding. 2012) memaparkan seseorang menentukan karirnya adalah dengan menggabungkan faktor hereditas yang mencakup lingkungan budaya baik orang tua dan teman sebagai patokan yang dianggap memiliki pengaruh dalam mengambil keputusan karir individu. Jika dipahami lebih dalam maka peran serta lingkungan sangat mempengaruhi pemahaman siswa terhadap diri sendiri. Individu mempunyai tujuan hidup serta tujuan atau pandangan yang ingin dicapai. Pandangan yang masih bersifat harapan akan diri sendiri di masa depan adalah bentuk cita-cita ideal yang sudah dapat dibentuk dan dipersiapkan 
sejak jenjang SD. Pemahaman diri yang baik dapat mengerucutkan cita-cita ideal berdasar kemampuan diri.

Pemahaman diri erat kaitannya dengan memahami kecenderungan karakter diri. Di jenjang sekolah dasar sangat tepat untuk membekali siswa untuk segera menganal diri. Kemampuan siswa untuk lebih tanggap dalam mengenal diri akan menentukan banyaknya alternatif peluang karir. Oleh karena itu, Holland berfokus pada individu harus memiliki pemahaman diri yang mencakup pengetahuan diri dan lingkungan pekerjaan sehingga akan lebih mudah untuk meregulasi konsep pemahaman karir.

Tipe kepribadian yang dapat disesuaikan dengan pemilihan dan pemahaman karir didasarkan pada kebiasaan-kebiasaan dan kecenderungan-kecenderungan seseorang berperilaku. Holland (1985) mengelompokkan model lingkungan tempat masyarakat tinggal menjadi enam model berdasarkan ciri orang yang tinggal dilingkungan tersebut. Enam model lingkungan ini didasari prinsip bahwa orang-orang yang memiliki tipe kepribadian yang sama akan berkumpul dan bekerja bersama sehingga membentuk lingkungan yang cocok dengan tipe kepribadiaanya. Model lingkungan itu adalah model Realistic, model Investigatif, model Artistik, model Sosial, model Enterprenuer dan model Konvensional. Holland memberikan tiga asumsi tentang model lingkungan tersebut. Masing-masing lingkungan akan menunjukan karakteristik yang berbeda-beda, karakteristik tersebut sesuai dengan karakter orang-orang yang tinggal dalam lingkungan tersebut.

Hasil temuan penelitian berikutnya adalah subjek mengalami kenaikan skor pada aspek pemahaman dunia kerja. Pemahaman dunia kerja mencakup: Kompetensi untuk memasuki suatu pekerjaan industri tertentu, Budaya industri yang mempengaruhi kesuksesan kerja, Prospek pekerjaan di masa datang, Pengaruh perkembangan ilmu pengetahuan dan teknologi. Beberapa indikator tersebut dapat dikatakan sebagai faktor eksternal yang mempengaruhi pemahaman karir siswa.

Pemahaman karir yang dibagi menjadi pemahaman diri dan pemahaman dunia kerja menguraikan bahwa pemilihan karir seseorang dapat dipengaruhi kepribadian diri. Seseorang yang menggabungkan kepribadian dengan pilihan karir, mendapat kenyamanan lebih baik dalam mengerjakan pekerjaannya sehingga usia dan jenjang karirnya akan lebih stabil. Pemahaman karir harus dilakukan dengan serius dan dengan pertimbangan yang matang.

\section{KESIMPULAN DAN SARAN}

Berdasar hasil penelitian dapat diperoleh kesimpulan layanan informasi menggunakan papan bimbingan dapat mempengaruhi pemahaman karir siswa sekolah dasar. Analisis kelompok dilakukan dengan cara mentabulasi dan menggambarkan grafik skor pretest, treatment I, treatment II, treatment III, dan postest. Adapun target pemahaman karir yaitu: Pemahaman Diri dan Pemahaman Dunia Kerja. Saran yang dapat berikan adalah pemanfaatan dari segi teoritik, temuan teoritis dalam penelitian ini dapat dijadikan sebagai informasi pemahaman kari di sekolah dasar.

\section{DAFTAR RUJUKAN}

Cresswell, John W. 2012. Educational Research: Planning, Conducting and Evaluating Quantitative and Qualitative Research. Boston: Pearson Education.

Depdiknas.2007.Rambu-Rambu Penyelenggaraan Bimbingan dan Konseling dalam Jalur Pendidikan Formal.Jakarta. 
Fitrianti, Abd. Munir, \& Munifah. 2017. Pengaruh layanan informasi Kebersihan Kelas Disertai Papan Bimbingan Terhadap Perilaku Menjaga Kebersihan Kelas Siswa SMP Negeri 13 Palu. Jurnal Konseling \& Psikoedukasi, Vol. 2 No.2, Hal. 1-14.

Frandikga, Agnes Sella Inu \& Hartini, Sri. 2018. Pengaruh Layanan Informasi Dengan Media Papan Bimbingan Terhadap Sikap Kemandirian Siswa Kelas XI IPS 3 SMA Negeri 6 Surakarta Tahun Pelajaran 2017/2018. Medikons, Vol 4, No 2, Hal. 1- 9.

Gibson, Robert L dan Marianne H. Mitchell. 2011. Bimbingan dan konseling. Yogyakarta: Pustaka Pelajar.

Gladding. 2012. Konseling: Profesi yang Menyeluruh (Edisi Keenam). Jakarta: Indeks.

Holland J. 1985. Making Vocational Choices A Theory Of Vocational Personalities \& Work Environments. Prentice-Hall: New Jersey.

Wijaya, Aditya Dani. 2017. Tingkat Pemahaman Karier Siswa SD Kelas Rendah Di Kecamatan Banguntapan, The Level Of Understanding Career Of Low Grades Elementary School. E-Journal Bimbingan dan Konseling UNY, Vol. 6, No. 3, Hal. 239-251. 